\title{
The EXCITE Grant: A Case in Innovative Library Professional Development
}

Joshua C. Elliott

Follow this and additional works at: https://digitalcommons.fairfield.edu/education-facultypubs Copyright 2019 Taylor \& Francis

The author post-print has been archived here with permission from the copyright holder. This is an Accepted Manuscript of an article published by Taylor \& Francis in Public Library Quarterly on 12/15/2019, available online: http://www.tandfonline.com/10.1080/ 01616846.2019 .1703465

\section{Peer Reviewed}

\section{Published Citation}

Joshua C. Elliott (2019) The EXCITE Grant: A Case in Innovative Library Professional Development, Public Library Quarterly, DOI: 10.1080/01616846.2019.1703465

This item has been accepted for inclusion in DigitalCommons@Fairfield by an authorized administrator of DigitalCommons@Fairfield. It is brought to you by DigitalCommons@Fairfield with permission from the rightsholder(s) and is protected by copyright and/or related rights. You are free to use this item in any way that is permitted by the copyright and related rights legislation that applies to your use. For other uses, you need to obtain permission from the rights-holder(s) directly, unless additional rights are indicated by a Creative Commons license in the record and/or on the work itself. For more information, please contact digitalcommons@fairfield.edu. 
The EXCITE Grant: A Case in Innovative Library Professional Development 


\begin{abstract}
Libraries programs are sometimes offered on a trial and error basis. The EXCITE program offers an intensive professional development experience. This experience is designed to help librarians develop their ability to identify community needs and develop innovative programs to meet those needs. The program ran on a cohort basis with six out of the twelve applications being accepted. Library cohorts that successfully finish the program are awarded partial funding to implement what they create.
\end{abstract}

Keywords: Professional development, library, adult learning, innovation 
Libraries offer a wealth of resources beyond books to the communities they serve. These resources come in many forms ranging from adult education classes on various topics to SAT exam preparation sessions to electronic resources like Great Courses. Matthews (2019, p. 235) argued that libraries should be "a place that celebrates creativity, encourages discovery and exploration, helps people to work productively, and provides community engagement and empowerment". However, the 2018 State of American Libraries Report stated that there is a clear disconnect between services offered by public libraries and public awareness of these services (2018). This was despite a majority of voters stating that they see the value of public libraries. These resources can often be chosen in a random fashion by librarians without thought about public needs or demands. The result can be a hit or miss approach to public library program development. This approach leads to programs that are underutilized or areas of need that the library could address but do not.

The EXCITE (EX Collaboration Innovation, Transformation, Entrepreneurship) program was created as an opportunity to remedy this. The funding for this project was provided by the Laura Bush 21st Century Librarian Program award from the Institute of Museum and Library Services. Ideally, participants in the EXCITE program could learn to better identify and meet the needs of the communities they serve. The EXCITE Transformation for Libraries program was created to help library staff improve their innovation and experimentation skills. The long terms goals of the EXCITE program are:

- To cultivate the next generation of library leaders and to improve librarians' skills in leadership and community engagement 
- Help build library leaders who are true collaborative innovators

- Training will result in new programs and services that uncover and respond to community motivations and needs, bringing more community members to the library to connect and collaborate

- Training will lead to cultural change at libraries change in skill set and mindset in librarians that encourages innovation and experimentation at their libraries.

- Impact on library school curriculum to teach innovation, collaboration, experimentation

Although more common in academic libraries, professional development opportunities are not commonly available for public librarians (Harker, O'Toole, \& Sassen, 2018). The professional development delivery could be described as experiential. Experiential learning involves the following factors:

- Learner involvement,

- opportunities for students to take initiative and make decisions, and

- natural consequences (Blair, 2016).

Research shows a preference for active learning to passive reception of information (Reichert, 2016; Rymarczyk, 2019). Professional development should also have relevance to participating individuals to increase engagement (Elliott, 2017). 


\section{Research Questions}

Opportunities for professional learning can be valuable in any field. Libraries are often underutilized resource to the communities they serve. The librarians in these libraries have expressed a hit or miss approach when developing programs (CT State Library: Division of Library Development, 2019a). Two qualitative research questions will guide this article:

- Can a professional development program be developed to help librarians learn how to better serve their communities?

\section{The EXCITE Program}

The EXCITE program presented an opportunity to work with public and academic librarians to help them create programs with greater relevance to the communities they serve rather than a hit or miss approach. The participants created real world projects with direct application to their workplaces. Instruction with a more direct delivery approach happened in the boot camps. Participants learned strategies for innovation and strategies for determining community demand. For the purposes of this initiative, innovation was defined as the ability to find improved ways of creating and implementing programs that met the needs of the communities they serve. They used the time following the initial boot camp to gauge what programs might be successful in their own communities and then develop a proposal for bringing this program to life. The groups then pitched their proposals to a panel of experts in a shark tank scenario.

The cohort lasted one year (January 2018 to December of 2018) and was broken into two stages, boot camp and application. Stage one, boot camp, went from January to May. This stage included three 3-day face to face sessions with several interspersed 
telecoaching and virtual sessions. Stage two was fieldwork with mentoring. The end goal was implementation.

\section{Goals, Objectives, Outcomes:}

Goal 1: Improve northeastern librarians' skills in 21st-century leadership, true collaboration, innovation, community engagement and understanding, and project management.

Goal 2: Enable teams to activate a space, program, or service for community members to come together at the library to collaborate in a meaningful and enjoyable way.

Objective 1:_Offer a training program in which librarians learn how to innovate and collaborate as teams working on a new program or service to address a community need.

Objective 2: Provide funding to and support for participating teams to enact the new program or service at their library or in their community.

Outcome 1: $100 \%$ of participants will indicate an increase in skills and indicate confidence that they will apply what they learned.

Outcome 2: Organizational culture at $90 \%$ of participating libraries will change, as shown through cross-department collaboration and the use of newly learned techniques in everyday settings.

Outcome 3: $100 \%$ of new programs and services will improve partnerships, patron participation, and patron benefits. 


\section{Method}

The EXCITE cohort consisted of a small group of staff members from six libraries. Five libraries were public libraries and the remaining was a higher education library from a local state university. Participants were selected using the following criteria:

- Commitment to attending all training dates and conducting field work

- Responses that align with the curriculum and program

- Personalities exhibited in applications - looking for energy and interest in collaboration

- Geographic distribution

- Diverse types of libraries, librarians, and communities

- Individual applicants for the Standalone Bootcamps must work at a library that has already participated in the pilot or in the full Core Program (Connecticut State Library: Division of Library Development, 2019a).

Twelve libraries applied to participate in the first EXCITE cohort. The EXCITE team accepted six of these groups into the first cohort. Groups came from multiple states, the farthest being North Carolina. Group size ranged between three and five members. Each group planned, proposed, developed, and presented on a topic of their choosing. As the time this article, all six library projects were still active. Their projects and purposes included:

- ConnectU: Fall Into the Library (Elihu Burritt Library Central Connecticut State University): To build connections between the library and junior faculty, and to facilitate connections with colleagues across multiple disciplines to solve current issues and get inspired by each other. Working with the Center 
for Teaching and Faculty Development, the library will offer a series of discussions in the fall semester aimed at helping junior faculty make connections across departments and help to change the campus culture (Connecticut State Library: Division of Library Development, 2019b).

- Drop The Mic Recording Studio (Charles County Public Library): To provide Charles County youth with a sense of belonging and a creative outlet, the library will set up a recording booth with equipment and software for recording music and podcasts, with accompanying programming and themes designed by the teens (Connecticut State Library: Division of Library Development, 2019c).

- Adulting 101(Hall Memorial Library): To provide social and learning connections for new adults, who may be feeling lonely and insecure in new environments and life situations. Young adults ages 23-29 who may feel that they are "adults without a handbook" can participate in a series of interactive workshops on subjects of their choosing to learn together in a conversational, comfy setting at the library (Connecticut State Library: Division of Library Development, 2019d).

- Parent Connections (Ossining Public Library): To connect parents who may be feeling isolated and overwhelmed, and to foster multicultural exchange and understanding. The library will connect parents with their children, themselves and their community through a program that includes a storytime or short activity for parents and children together, dedicated time for parents to learn something for themselves, and social time when parents can connect 
with the other parents in the group (Connecticut State Library: Division of Library Development, 2019e).

- Unite Teams (Springfield Library): To provide consistent, inclusive activities for teens in order to encourage connections and a sense of community. The library will provide a variety of inclusive activities for teens in a safe space and with consistent staffing to help the teens find connections with each other and with their community (Connecticut State Library: Division of Library Development, 2019f).

- Forward Together (State Library of North Carolina): To help librarians find a way to address complex community issues and form meaningful partnerships, with a focus on poverty. The State Library of North Carolina will offer a two and half day intensive seminar with virtual follow-up meetings for library staff and their community partners to examine the issue of poverty in depth with expert speakers, a poverty simulation exercise, panel discussions, and empathy training (CT State Library: Division of Library Development, 2019g).

All research is subject to potential bias. Qualitative and a mixed method research is particularly subject to bias. Triangulation of data was used to minimize bias. Three data sources used in this project included a survey, participant interviews, and evaluator feedback. The surveys were done in a pre-test/post-test design. The questions in the pre and post surveys were identical with only the word tense changed to reflect the administering of the survey in relation to the workshops. The survey can be viewed in Appendix A. The survey was created by the grant evaluator using Google Forms and 
administered via an email link during the relevant boot camp session. The survey was reviewed by the grant administrator to ensure if met the needs of the grantor.

The second source of data collection was participant interviews. An interview guide was used to maintain continuity throughout the interviews. The guide was created by the grant evaluator and reviewed for effectiveness by the program administrator. The interview questions can be found in Appendix B. All 24 cohort participants were interviewed. 22 were interviewed in person. The remaining two were interviewed by recorded videoconference. The average interview length was eight minutes. Interviews were recorded and transcribed for analysis. The transcriptions were coded and analyzed using NVIVO software. The results of this coding were reviewed for themes and patterns.

The third source of data was evaluator feedback. Each group presented their final project to a review panel at the end of the boot camp. The review panel was comprised of pilot participants and local business owners. The panels evaluated the cohort groups on the following criteria:

- User engagement

- Engaged users in defining the problem

- Understood user motivations and needs - both functional and emotional

- Solicited feedback on program design to iterate

- Developed a clear value proposition relevant to user and their underlying needs

- Problem, value proposition, benefits 
- Problem is well defined and relevant

- Value proposition is clear and relevant

- The benefits of the program/service are clear

- Market

- Understood/considered the market, trends

- Understood users' alternatives to their concept

- Differentiated their offering vs alternatives

- Clear \& motivating message that communicates the value proposition and differentiation

- Design of program/service

- Provides engaging user experience

- Addresses the problem and user motivations that were identified

- Delivers the value proposition in an innovative way

- Design integrated user input \& feedback in its iterations

- Structure

- Business model is feasible \& effective

- Appropriate/Reasonable use of resources vs. impact

- Clear Support for program/service from internal stakeholders

- Clear Support for program/service from community partners

- Impact of program on users, library \& community is clearly articulated

- Implementation

- Clear implementation plan - timing, resources, staffing 
- Considers on-going improvements via community input

- Articulates an effective plan to recruit users

- Design team

- Team represents a diversity of skills, experience \& styles

- Good team dynamics: clear collaboration and group involvement

- Showed passion for the program/service they are pitching

- Knowledgeable response to questions

- Presentation

- Motivating/Engaging presentation

- Integrated storytelling into presentation

- Good organization, professionalism, visuals

- Content supported by facts and insights

\section{Data Analysis Process}

All data was analyzed both on their own and against each other. The quantitative data from the surveys and evaluator feedback data were entered into Excel spreadsheets and reviewed for trends and possible emerging themes. The qualitative data from the interview transcripts and the open-ended survey questions were also reviewed for trends and commonalities in participant responses. All data source results were then compared to each other. In addition to trends and themes, the data was also reviewed for inconsistencies at this level. This was done as part of the triangulation process to ensure validity to the results.

\section{Results}


The three sources of data were fairly consistent with each other. Participants noted improvements in their skills over the course of the program.

\section{Pre-test/Post-test}

The averages for perceived change in leadership skills, project management skills, and ability to engage the community increased for all participants (Table 1).

Table 1: Pre-Test and Post-Test Results

\begin{tabular}{|l|l|l|}
\hline \multicolumn{2}{|l|}{ How would you rate yourself as a leader? } \\
\hline Pre-Test (24 responses) & Post-Test (18 responses) & Difference \\
\hline 3.541666667 & 3.722222222 & 0.180555 \\
\hline How would you rate yourself as a project manager? & Difference \\
\hline Pre-Test & Post-Test & 0.31944444 \\
\hline 3.458333333 & 3.777777778 & Difference \\
\hline How effective are you at engaging your community? & Post-Test & (3.833333333 \\
\hline Pre-Test & 3.25 &
\end{tabular}

Each category (leadership, project manager skill, and engagement showed an increase.

However, these increases were not seen in every participant. Six participants did not respond to the post-test survey and between two and five indicated a decline in perceived skill (Table 2). The numbers provided in Table 1 reflect the average of all participants as a whole. 
Table 2: Breakdown of perceived changes by participant

\begin{tabular}{|l|l|l|l|l|}
\hline Question & Same results & Improved & Declined & $\begin{array}{l}\text { No second } \\
\text { response }\end{array}$ \\
\hline $\begin{array}{l}\text { How would you } \\
\text { rate yourself as } \\
\text { a collaborator }\end{array}$ & $5(21 \%)$ & $8(33 \%)$ & $5(21 \%)$ & $6(25 \%)$ \\
\hline $\begin{array}{l}\text { How would you } \\
\text { rate yourself as } \\
\text { a leader? }\end{array}$ & $6(25 \%)$ & $7(29 \%)$ & $5(21 \%)$ & $6(25 \%)$ \\
\hline $\begin{array}{l}\text { How would you } \\
\text { rate yourself as } \\
\text { a project } \\
\text { manager? }\end{array}$ & $8(33 \%)$ & $7(29 \%)$ & $3(13 \%)$ & $6(25 \%)$ \\
\hline $\begin{array}{l}\text { How effective } \\
\text { are you at } \\
\text { engaging your } \\
\text { community? }\end{array}$ & $7(29 \%)$ & $9(38 \%)$ & $2(8 \%)$ & $6(25 \%)$ \\
\hline
\end{tabular}

\section{Interviews}

Several themes emerged during the interviews, both positive and negative. The three most prevalent positive themes were 1) change in thinking, 2) improved ability to reach others, 3) improved collaboration (Figure 1). The positive changes could be described as dispositional changes. The majority of the participants described how their ability to collaborate, identify needs and connect with potential library users in the community. In contrast, the three most prevalent negative themes could be described as suggestions for design or procedural changes. The negative themes were 1) disconnected activities, 2) too much paperwork, and 3) could have been done in less 
time (Figure 2). These themes were issues that could be addressed fairly simply through changes to scheduling and how materials are provided (electronically rather than hard copy).

\section{Figure 1. Positive Themes}

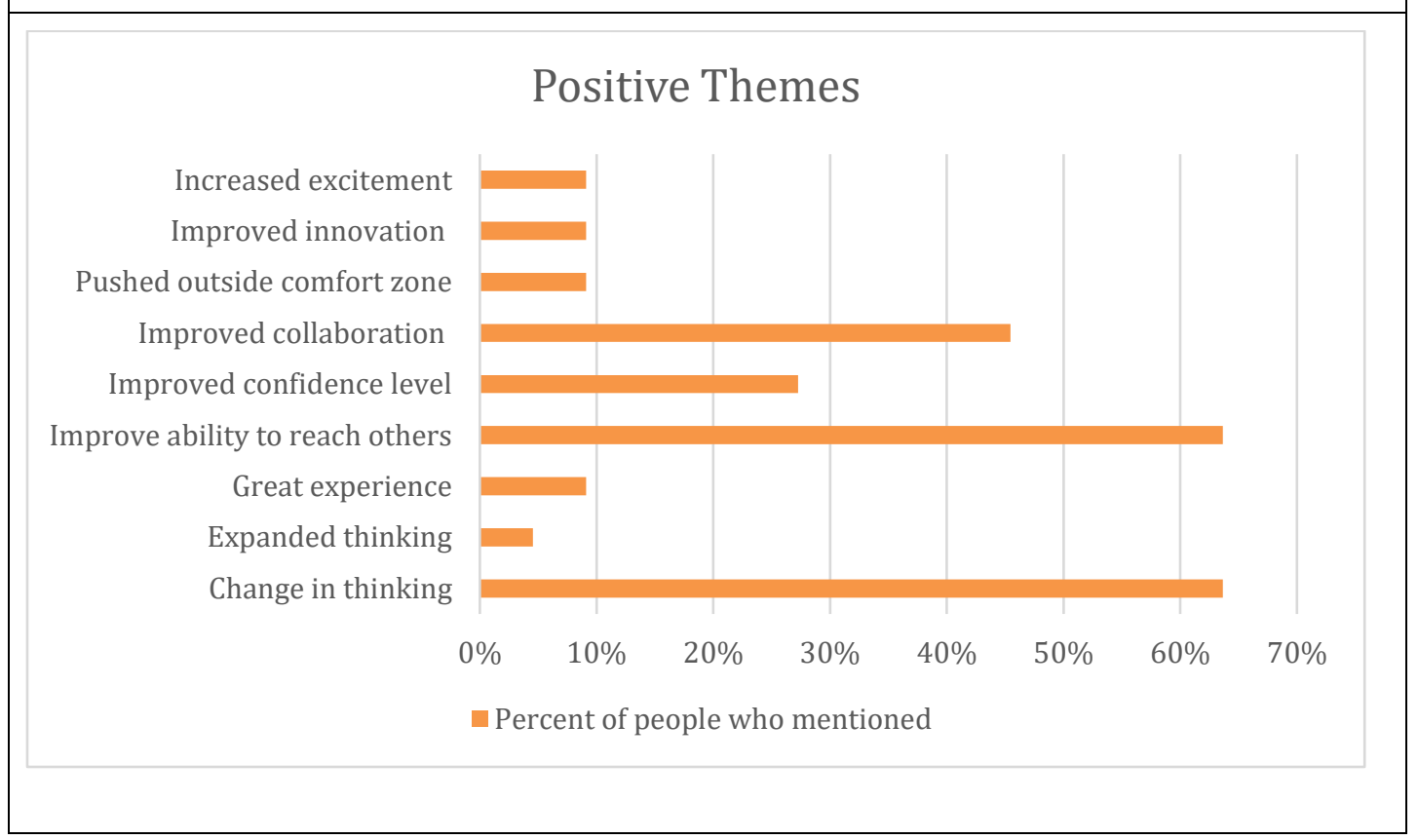

Figure 2. Negative Themes 


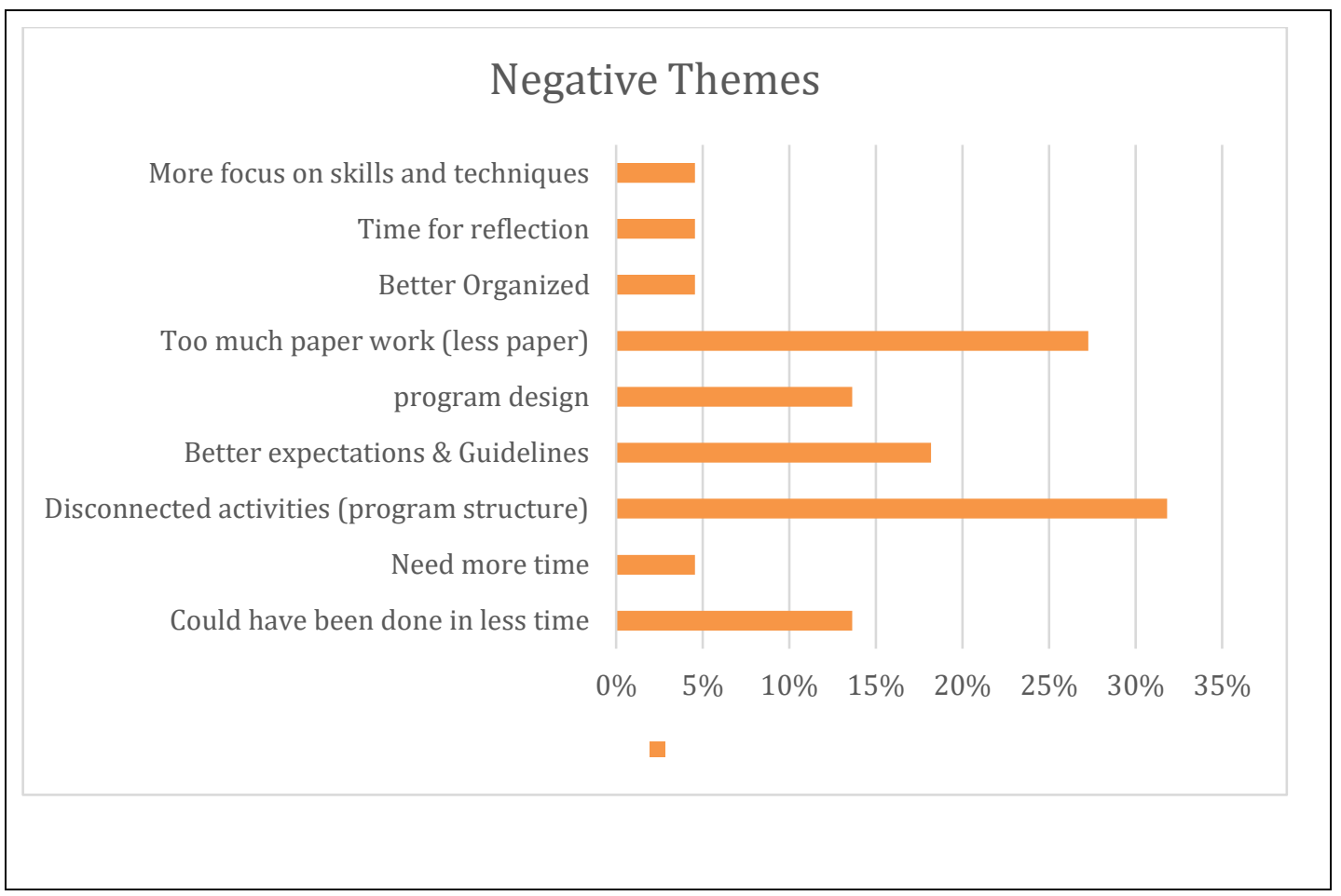

\section{Judging Feedback}

The pitch session was an opportunity for the cohort members to share their ideas with professionals who had not been involved with the creation process. This enabled them to potentially offer feedback from a fresh perspective.

Figure 3. Judging Feedback 


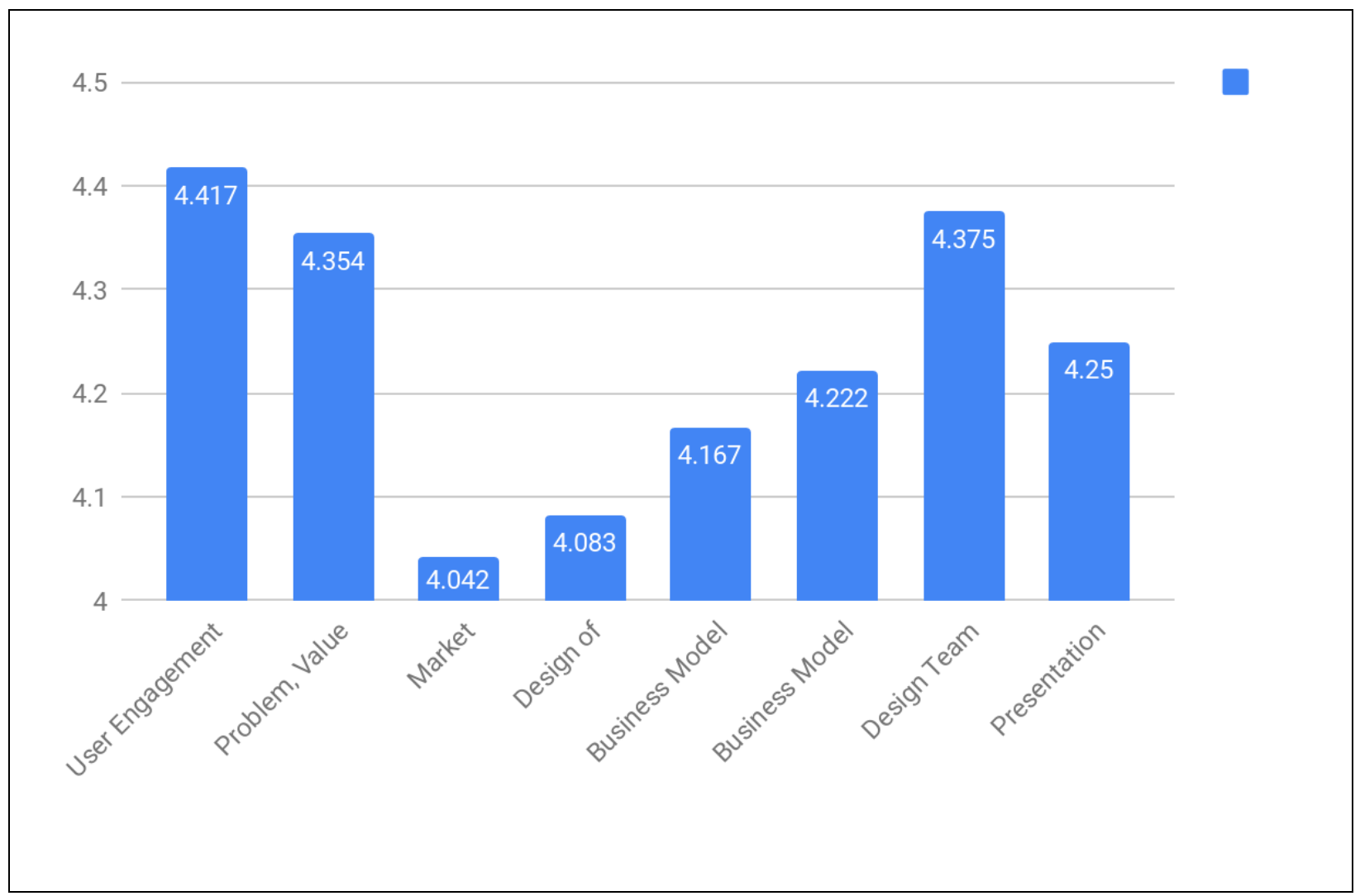

\section{Discussion and Conclusion}

The results of the study indicate that the delivery approach had value.

Suggestions and critiques primarily dealt with logistical details rather than significant content or delivery issues. Of the twelve libraries who applied, six groups of between three and five members were selected to participate. Each group presented to the panel. Their proposals were approved and received some funding through the grant to partially support their initiatives. Several participants expressed that they found the learning experience to be very useful and relevant for their profession. They described changes in thinking, improved collaboration skills and ability to reach others. Suggested program and delivery changes were limited to suggestions for scheduling and 
organization. All six groups in the cohort are still active with their programs at the time of this writing.

The initial research question put forth earlier in this article was:

- Can a professional development program be developed to help librarians learn how to better serve their communities?

The evidence indicates that this can be done. Conducting research for this article also revealed how little research exists on the topic. This article does show that it is possible to create a professional development program for librarians. However, it also shows the need and benefits for librarians and the communities they serve. The EXCITE grant shows evidence of not only how it can be done but also that it needs to be done. The success of the cohort led to additional grant funding. A similar project with a second cohort is currently underway. 


\section{Appendix A: \\ Pre-test/Post-test Survey \\ Survey}

1. How would you rate yourself as a collaborator?

2. How would you rate yourself as a leader?

3. How would you rate yourself as a project manager?

4. How effective are you at engaging your community?

5. What are the three main things (skills, knowledge, information, etc.) you got from this experience? 
Appendix B:

Interview Guide

1. How do you feel that this boot camp has changed you in regards to your professional mindset or confidence level? Explain.

2. Has your work here affected your perceptions of the 21st Century Skills:

Collaboration, Innovation, Transformation, and Engaging Community?

3. How about the role of the library and their role or relationship with the 21 st Century Skills?

4. How do you feel any or all of these changes will become apparent in your library? Give examples.

5. Was there anything in the boot camp that seemed out of place?

6. Was there anything that you felt was missing?

7. Is there anything you would like the stakeholders of the Excite grant to know? 
Appendix C

Initial Survey Open-Ended Question Responses

\section{What are the three main things (skills, knowledge, information, etc.) you hope to get from this experience?}

New ideas, better teamwork skills, innovative thinking techniques

Knowledge how to create innovative programs

Open mind to silly or obscure ideas, confidence to advocate for my ideas, training skills to take back so I can teach this to coworkers

More creativity (thinking outside of the box), something truly workable, better understanding of my coworkers.

Better collaborative skills and a feasible statewide project

1. Learn how to facilitate collaborative meetings.

2. Learn how to listen with more attention to detail.

3. Learn how to synthesize my ideas better and to express my ideas in a clearer manner.

Information on how to identify needs and best engage our community, plan effective and engaging programs, and also improve upon existing outreach methods in my area of specialty.

How to engage community more, how to develop pertinent programs, how to use innovative thinking in other areas.

How to find out what the community really wants from the library, how to work more effectively with library staff, how to form new partnerships

Skills, knowledge, confidence

How to transform the library to listening to what the community wants instead of telling them. Ideas for the future of the library. Programming ideas.

How to create safe spaces for idea sharing, methods for engaging/understanding non-users, iterative design methods

Collaboration techniques. A new view. Re-energized

Collaborative and innovative skills 
Better Listening, better empathy, ways to get outside the box.

How to incorporate new creative ideas, how to collaborate better, and to implement some new goals that I will gain from this training.

1. Presentation skills 2 . Knowledge of project management 3 . How to promote more collaboration among my staff.

To be more innovative and think differently. To serve community better. Gain leadership skills

Ways to be a good collaborator since I largely work alone in my work and how to be more creative when looking for solutions to library problems

Leadership skills, outreach, problem-solving

Increased comfort in collaboration, new tools to lead collaborative efforts, networking and info gathering from other libraries

How to work better with groups. How to become a better leader. To develop a worthwhile program or project for our library. 
Appendix D

Final Survey Open-Ended Question Responses

\section{What are the three main things (skills, knowledge, information, etc.) you got from this experience?}

Great ideas for creating at work, networking, a new way to visualize collaborating

Effective way of creating new programming for our customers, out of the box thinking techniques for ideation, new vocabulary for collaborative thinking

Feel more comfortable speaking to the community, importance of identifying functional and emotional drivers, some great new ways to "brainstorm" ideas

How to plan better, how better to deal with people and how to sell my ideas

Better understanding of collaboration, ways to have better conversations with public to get quality feedback, tools to foster innovation with my staff

How to understand my patrons and their needs better. How to do an effective pitch presentation. How to approach things more positively

How to run a better feedback session.

Information, communication skills, confidence

Listening to feedback, ideation, and the importance of collaboration

I learned how to collaborate more efficiently with my co-workers and community. Using the empathy map has really helped be a better listener. I am more confident presenting in from of groups now.

Solve-fors; empathy maps; how to give and get good feedback

1. How to make a worst idea into a good idea 2. How to properly do a Power Point Presentation 3. The tools I got from this experience has definitely help me implement the information from this course into my community

Better self-knowledge...I learned I CAN do this, but also things I need to work on!

Skills of soliciting and understanding feedback, skills for leading ideation processes, and skills for presenting a project

Connecting with co-workers and supervisor, learning not to assume what others need/think, experience with defending a grant application

Think of all the possibilities because you don't know where it might lead you in terms of developing something patrons want, feeling like I am part of a team is really important to me and my colleagues, and slowly I am becoming more comfortable with things outside my comfort zone like making a presentation asking 
for money from strangers.

I learned how to work better with my staff

I learned how to better conduct a focus group

I learned how to base programs on the needs of the community

Networking, preparation, innovation 
Appendix E:

End of Cohort Exit Interview

\begin{tabular}{|l|l|}
\hline Label Name & Extracted Text \\
\hline Pro & $\begin{array}{l}\text { The program was run well and efficiently and the information that I } \\
\text { learned will stay with me for the rest of my library career, } \\
\text { Janine and Dawn and the staff at the State Library are great! Very } \\
\text { respectful, helpful and patient. } \\
\text { In the end I think things turned out alright but the projects could } \\
\text { have been even stronger if the group was more cohesive and } \\
\text { already in the mindset of "outside the box." So, when new cohorts } \\
\text { are advertised I would recommend putting in some language } \\
\text { around that. } \\
\text { I think that somehow, activities should be rolled into the training } \\
\text { that support this broader focus. }\end{array}$ \\
\hline Con & $\begin{array}{l}\text { The amount of material being learned in such a condensed format. } \\
\text { Often working from 9:00am until past lunchtime without stopping, } \\
\text { and then going past 5:00pm before we finished. } \\
\text { It isn't wise to start off the training on the first day by talking about } \\
\text { difference between people, since if someone feels they are being } \\
\text { poorly represented, that tends to get them started on the wrong } \\
\text { foot. } \\
\text { I don't necessary think that our choices were accepted as easily as } \\
\text { they should have been since we know our institution and } \\
\text { understand our goals as a library } \\
\text { It felt like we were being pushed to pick one that others felt was } \\
\text { better for the purposes of the EXCITE program. } \\
\text { Communications regarding the follow-up phone meetings could be } \\
\text { done with more advance notice. This did seem to improve over } \\
\text { time. }\end{array}$ \\
\hline
\end{tabular}




\begin{tabular}{|c|c|}
\hline & $\begin{array}{l}\text { You can see the last } 2-3 \text { hours of each day, everyone seems a } \\
\text { drained. It also can be overwhelming as it is a crash course. } \\
\text { I observed a couple of groups experiencing some conflict that } \\
\text { threatened to derail their work. For those who are more used to } \\
\text { traditional library work, it was also harder for them to grasp the } \\
\text { concepts } \\
\text { The emphasis on putting together and implementing a new } \\
\text { program for our library, while good practice using the methods that } \\
\text { we learned, took up so much of our time and energy that we were } \\
\text { unable to focus on rolling out the Excite principals to the rest of our } \\
\text { staff. }\end{array}$ \\
\hline Suggestion & $\begin{array}{l}\text { Have smaller sections of training broken up by quick breaks-15 } \\
\text { minutes or so-so we can all take in more and retain it better. } \\
\text { There's a phenomenon in psychology called chunking that is used } \\
\text { in learning new material (for example in the pomodoro method) } \\
\text { whereby you study for a block of time-maybe an hour or } 45 \\
\text { minutes_-then take a short break and do something unrelated in } \\
\text { that time before starting up again in order to maximize the effects } \\
\text { of recency and primacy. } \\
\text { Talking about any kind of differences between groups of people is } \\
\text { probably something to save for later in the session, when rapport } \\
\text { has already been established. } \\
\text { I would think that it be important for the learning process to allow } \\
\text { each library to have missteps like picking a target segment that } \\
\text { might not be appropriate to truly understand the motivations of the } \\
\text { segment and realize a deviation needs to be made. } \\
\text { Even something as traditional as a book discussion can still } \\
\text { position a library to meet a target segments motivation and provide } \\
\text { the desired connection between members of the community. It } \\
\text { should be accepted that when a library group does the work and } \\
\text { something not quite innovative or exciting is discovered as the } \\
\text { preferred means for collaboration. }\end{array}$ \\
\hline
\end{tabular}


The training could include more practical/specific advice and training on how to incorporate design thinking into the running and daily activities of a library.

I believe the days should be shorter in length. Perhaps add a day to each session or add another 3-day session to shorten the days.

The interactive segments of the sessions are great for a change of pace and getting to know your peers. They should definitely do at least a few of those each day to get rid of the classroom feel as it sometimes gets.

There were discussions in the training and in the follow up phone calls of working the methods and philosophies in our everyday work, but I think that it should be a much bigger emphasis. 


\section{References}

American Library Association. (2018). State of America's libraries. Retrieved from:

http://www.ala.org/news/sites/ala.org.news/files/content/2018-soal-report-final.pdf

CT State Library: Division of Library Development (2019a). EXCITE Transformation for

Libraries. Retrieved from: https://libguides.ctstatelibrary.org/dld/EXCITE/home

CT State Library: Division of Library Development (2019b). EXCITE Transformation for

Libraries. Retrieved from: https://libguides.ctstatelibrary.org/dld/EXCITE/CCSU

CT State Library: Division of Library Development (2019c). EXCITE Transformation for Libraries. Retrieved from: https://libguides.ctstatelibrary.org/dld/EXCITE/CCPL

CT State Library: Division of Library Development (2019d). EXCITE Transformation for Libraries. Retrieved from: https://libguides.ctstatelibrary.org/dld/EXCITE/Hall

CT State Library: Division of Library Development (2019e). EXCITE Transformation for Libraries. Retrieved from: https://libguides.ctstatelibrary.org/dld/EXCITE/Ossining CT State Library: Division of Library Development (2019f). EXCITE Transformation for Libraries. Retrieved from: https://libguides.ctstatelibrary.org/dld/EXCITE/Springfield

CT State Library: Division of Library Development (2019g). EXCITE Transformation for Libraries. Retrieved from: https://libguides.ctstatelibrary.org/dld/EXCITE/SLNC

Blair, D. (2016). Experiential learning for teacher professional development at historic sites. Journal of Experiential Education, 39(2), 130-144. https://doi.org/10.1177/1053825916629164 
Elliott, J. (2017) The evolution from traditional to online professional development: A review. Journal of Digital Learning in Teacher Education 33.3: 114-125. Retrieved from: https://digitalcommons.fairfield.edu/education-facultypubs/130/

Harker, K., O’Toole, E., \& Sassen, C. (2018). Assessing an Academic Library Professional Development Program. Portal: Libraries and the Academy, 18(1), 199-223. https://doi.org/10.1353/pla.2018.0010

Islam, A., Agarwal, N. K., \& Ikeda, M. (2017). How do academic libraries work with their users to co-create value for service innovation?: A qualitative survey. Qualitative and Quantitative Methods in Libraries, 4(3), 637-658.

Jantz, R. C. (2012). A framework for studying organizational innovation in research libraries. College \& Research Libraries, 73(6), 525-541.

\section{https://doi.org/10.5860/crl-302}

Malik, M. (2016). Assessment of a professional development program on adult learning theory. Portal: Libraries and the Academy, 16(1), 47-70. Retrieved from https://search-proquestcom.contentproxy.phoenix.edu/docview/1776311843?accountid=134061

Matthews, J. R. (2019). Engaging design: Creating libraries for modern users. Public Library Quarterly, 38(2), 235-239.Retrieved from:

\section{https://www.tandfonline.com/doi/full/10.1080/01616846.2019.1602750?af=R}

Reichert, C. S. (2016). An examination of professional development practices for secondary teachers through the lens of adult learning theory (Doctoral dissertation, University of Missouri--Columbia).

Rymarczyk, J. M. R. (2019). College Teachers' Perceptions of Technology Professional 
Development (Doctoral dissertation, Walden University). 